\title{
Taxation As A Fiscal Policy Instrument For Income Redistribution Among Lagos State Civil Servants. (A Case Study of Lagos State Civil Servants)
}

\author{
${ }^{1}$ Olusanya Samuel Olumuyiwa, ${ }^{2}$ Peter Medunoye, ${ }^{3}$ Oyebo Afees Oluwatosin \\ Lecturer Economics department Lagos State University, External System. \\ Assistant Director Lagos State Pension Commission \\ Lecturer Marketing Department, Lagos State University, External System \\ Pension Officer, Lagos State Pension Commission
}

\begin{abstract}
Abstarct: The research study vividly looks at Taxation as a Fiscal Policy Instrument for Income Redistribution among Lagos State Civil Servants, a case study of Lagos State Civil Servant. However, the research study make use of primary data analysis and questionnaire were distributed to one hundred and fifty (150) respondents civil servant employee of Lagos State Government and spearman's rank correlation coefficient was adopted as the estimation techniques. More over, the objectives of the study is to examine whether taxation as a fiscal policy instrument can be used for income redistribution among the Lagos civil servants and also to examine whether Income re-distribution can improve the welfare of Lagos State Civil Servants. More so, two research hypotheses were tested using Spearman's rank correlation coefficient using 5\% level of significance and the result revealed that taxation as a fiscal policy instrument can be used for income redistribution among the Lagos civil servants and that income re-distribution has help to improve the welfare of Lagos State Civil Servants. Therefore the study then recommend and concludes that Government should create a transparent and accountable system to ensure that tax is used to build a more equitable society, redistribute wealth and attract investment flows into the state and Government should bridge the gap between the rich and the poor by taxing the rich high and using the tax proceeds to provide basic amenities for the masses in Lagos State.
\end{abstract}

Keywords: Taxation, Fiscal Policy issue, Income-redistribution, Investment flow, Wealth, Welfare, Civil Servant.

\section{Introduction}

Income redistribution by the price-mechanism will normally tilt in favour of those whose labour, by virtue of natural ability and acquired education and skills, command high wages. This implies that without government intervention, some people in our society who have less ability due to low level of education and training received, the aged who were not able to accumulate or inherit large property resources and those who are physically and mentally handicapped will receive no income at all through the price system. Thus, the price system promotes income inequalities thereby creating poverty and agony amidst overall plenty in the economy (Adebayo, 1999).

In view of the foregoing, government therefore, intervened to correct unjust inequality of income through the introduction of tax system, among other programmes, which is designed to take more from the rich and less from the poor.

Taxation as a concept involves more than the mere imposition of the compulsory payment of sums of money by the government or its agents. It is the sum total of the assessment of tax, the imposition of compulsory sums of money by the government or its agents. It is the sum total of the assessment of tax, the imposition of compulsory sums of money by the government or its agencies on individuals and firms, the collection of and the accounting for the levied amounts and the keeping and auditing of tax records (Anyanwuocha, 1993).

Different taxes contribute to the attainment of different objectives. Thus, some taxes would help in the redistribution of income and wealth more equitably.

A tax which tries to reduce income inequalities might discourage savings and investment and thereby retard capital accumulation and economic growth. It is, therefore, necessary that a judicious mixture of taxes be chosen so as to minimize their possible ill effects and strengthen their beneficial effects for the economy (Lawal, 2005).

This research work is an attempt to critically review the evolution and development of taxation in Nigeria, rules, concept and objectives of taxation, identify the attendant problems in the tax system and the manner in which taxation is being used as a fiscal policy instrument for income redistribution and economic development. It is intended to offer suggestion at improving the overall Nigeria tax system in order to enhance 
its effectiveness and efficiency. Thus improving tax payers' voluntary compliance and resultant increased revenue earnings to the government at reduced and reasonable cost. However, the debate between static and dynamic scoring of taxation as a fiscal policy instrument for income redistribution has a problem that great scholars have been looking for way forward. In the short-term better tax revenue estimating methods would make it easier to implement tax rate but a lot of shortcomings has not allowed the method to triumph in Nigeria.

However, even in the long term, shifting to a simple and fair revenue code would be expedited if Nigerian Government allows the tax revenue estimators to consider the beneficial impact of tax reform on economic performance.

When lawmakers consider tax revenue changes, Congress's Joint Committee on Taxation (JCT) and the Treasury Department's Office of Tax Analysis (OTA) are responsible for estimating the likely impact on future tax collections; but these estimates assume that tax revenue changes-regardless of their magnitude have no impact on the economy's performance due to a lot of problem such as corruptions, unqualified personnel to administered the tax revenue. As a result, these "official" estimates commonly overstate both the amount of tax revenue that will be generated by tax increases and the amount of revenue the government will "lose" due to tax rate reductions. This static methodology has been widely criticized because it provides policy makers with inaccurate numbers and creates a bias against lower tax rates.

Though defenders of the status quo argue that dynamic effects are incorporated into revenue forecasts, this claim is only correct for "microeconomic" changes. If asked to estimate the tax revenue impact on Nigerian economy, for instance, the various processes use by the Government to improve tax revenue in Nigeria has been regarded as non performance due to corruption both on the part of the tax collector as well as tax payer.

Missing from the equation, however, is any effort to capture the revenue effects caused by changes in macroeconomic variables. Within the static system, revenue estimators assume that economic growth, job creations, and income will remain unchanged regardless of how much taxes are reduced or increased on the Lagos Civil Servants.

In conclusion, if a reasonable system of taxation is to be achieved, people must recognize as a principle that the majority that determines what the total amount of taxation should be, must also bear it at the maximum rate, and the objectives of this research study is to examine the efficacy of taxation on income re-distribution on Lagos State Civil Servants and also to also examine whether the income - redistribution improve the welfare of Lagos State civil servants.

\section{Brief Literature Review}

Taxation plays a very important role in the economic life of a developing country like Nigeria. Today, Nigeria is indeed in dire need of effective and efficient tax system in order to generate enough revenue that will stimulate economic growth and development (Oji, 2000).

"One man's meat, they say, is another man's poison. Though taxation may be seen as a threat to individual's proposed standard of living or even business proposed revenue generation, but to the government and the fiscal need for taxation, it is the pillar and facilitator of development" (Business Day, August 13, 2007, pg. 29).

Nwabueze (2000) in his paper presentation on the topic "stimulating economic growth through an efficient tax system" asserts that the use of tax in national development is increasing and that further introduction of new technology will ensure its continued growth and influence in stimulating economic growth and development. He stressed further that "the real purpose of taxation is to take purchasing power from tax payers so that tax payers relinquish control over economic resources and make them available to state. In this direction taxes have an important effect on the redistribution of income among the poor and better-off household of the community".

One of the objectives of taxation is to ensure the redistribution of income and wealth (Olakunrin, 2000). Thus, taxation is used as a tool to achieve socially desirable goals (Olakunrin, 2000). Olakunrin stressed further in a talk delivered by her during the second Annual Tax conference of the Chartered Institute of Taxation of Nigeria (CITN), that taxes are generally based on the principle of ability to pay and that citizens who are well endowed invariably assessed for more taxes than their less fortunate compatriots. According to her, the taxes paid by the rich are used by government to provide social amenities for the poor. This is the essence of the principle of progressive tax that seeks to reduce inequality and redistribute income and wealth.

How effective is taxation as a tool for income redistribution? How is taxation being used as a tool to bridge the gap between the rich and the poor? Has taxation being fully employed to facilitate economic development in Nigeria, particularly among Lagos State civil servant? There are the questions that triggered this research.

However, tax means almost the same thing to everybody, be it layman or a professional, the only difference is in the definitions. Tax means the same thing to everybody in every society but seen from different angles: to government, it is a source of revenue; to company it is a cost; and to individual, it is a depletion of their income" (Agbetunde, 2004). "Tax; the imposition of compulsory sums of money by the government or its agencies on individuals and firms, the collection of and the accounting for the levied amounts and the keeping and auditing of tax records" (Anyanwuocha, 1993). 
More over, the Oxford English Dictionary defines a tax as "a compulsory contribution to the support of government levied on persons, property, income, commodities, transactions etc now at a fixed rate mostly proportionate to the amount on which the contribution is levied". A tax is a compulsory levy on individuals and business organization which the object of financing government expenditure (Ilemobayo, 1997). It is paid 'quid pro qui' i.e. without expecting something specific in return. "Alternatively, a tax may be defined as a liability imposed upon the tax assesses who may be individuals, groups of individuals, or other legal entities. It is a liability to pay an amount on account of the fact that the tax assesses have income of a minimum amount and from certain specified sources or that they own certain tangible or intangible property, or that they carry on certain economic activities which have been chosen for taxation" (Bhatia, 1976). Taxation on the other hand is the process of improving, assessing and collecting taxes (Agbetunde, 2004).

\section{Evolution Of Taxation In Nigeria}

Taxation is one of the oldest social economic concepts. Without sounding parochial or sentimental, one may recall for the purpose of historical authority the famous passage of "St Luke, 1: "And it came to pass in those days, that there went out a decree from Caesar Augustus, that all the world should be taxed". And ever since then all over the world from Nigeria to Tokyo and Tokyo to Lisbon the world has been rendering unto Caesar what is his $(\mathrm{Oji}, 2000)$.

"The history of man has shown that man from origin, had to pay tax in one form or the other, in cash or in kind, initially to his Chieftain and later on to a form of organized government. The people of the Niger Area, a terminology used to describe present day Nigeria with its diverse people and culture were not insulated from such traditional pre-colonial tax system" (Dada, 2007).

We shall now look at tax system in Nigeria under three periods viz: pre-colonial, colonial and post-colonial periods.

\section{Pre-Colonial Period In Nigeria}

"Before the advent of the British to West Africa, there were Empires, Kingdom and Emirates governed by the Obas, chiefs, Emirs and Sultans, They governed, administered, executed communal projects, provided securities and at times went into wars. All these were financed by the provisions from the people ruled either voluntarily or compulsorily. As such each empire or kingdom had a form of taxation in place, however primitive it was (Agbetunde, 2004). Agbetunde reviewed what obtained in this period by looking at Western, Northern and Eastern parts of Nigeria.

\section{Taxation In The Western Region In Nigeria}

There are documented evidences in the records of the British Colonialists on taxation in the Southern province consisting of Western and Eastern Regions. In these records it is appreciated that there were developed systems of taxation in Oyo and Benin Empires. It is on record that the Manor House, a Government VIP Rest House at Iseyin was built between 1916 and 1932 by community effort. Building of walls round the towns in Yoruba land to prevent external aggressions in the then Oyo Empire. These projects were all executed through what is called 'Owe', Others are tributes which were common among the Oyo, Egba and Benins. The Ijebus and Ondos derived most of their taxes from levies and tolls on traders and farm producers (Agbetunde, 2004).

These taxes were imposed by laws, custom and traditions. Rates were fixed by the Obas and the time of payment were usually in the time farm produces were harvested. There were -structured machinery established for collection and refusal to pay or payment below expectation is usually penalized (Agbetunde, 2004), Agbetunde identified some of these taxes to include:

"Owe": This is a form of lax made by every member of a community in kind to execute specific projectsFor instance, in the event of constructing roads, town walls or public buildings, men used to provide personal effort to work while the women used to cook the food for them to eat. 'Owe' is made when there is work to do on the kings' farms.

"Isakole": This is a form of tax levied as land rent paid by communities and families to the Obas and Chiefs. It is paid as allegiance to the ruler. The payment is made both in monetary and non-monetary forms.

"Owo Ori": This is a form of poll tax paid by every individuals in a community. Most of the time, payment is in cash. It is made mandatory as non-payment is severely penalized. Hence, Yoruba dictum of "dandan l'owo ori" meaning "poll tax is compulsory" (Agbetunde, 2004).

"Owo Ode": This is another form of poll tax levied on individuals in a community as occasional security tribute. It is paid usually in cash or produce on trades and farming

"War Returns": This form of tax is similar to the 'Isakole' but is payable by defeated community to the Victor on annual basis. It used to be in cash or in kind (Agbetunde, 2004). 


\section{Taxation In The Eastern Region In Nigeria}

Taxation in the East was the least developed of all the parts of the country, -This is due to the customs and traditions of Igbos, The Igbos lived in community of small families and in most instances without a constituted authority. Due to this structure, the Aba Women Riot of 1929 was not a surprise (Agbetunde, 2004). Agbetunde (2004), gave some identified taxes among the Igbos to include: "Egbu-Nkwu": This is a form of tax on farm produce like palm kernel when harvested. Payment is usually made in cash to the village council for the development of the community, "Community Effort": Here, members of the village are made to participate in the execution of communal projects.

\section{Taxation In The Northern Region In Nigeria}

"There existed in the Northern Region an efficient and stable administration based on Islamic system. Uthman Dan Fodio established an Islamic system of government that was adopted by his successors. Under this system of government there existed a central authority at Sokoto with Emirs as governors in other cities and towns under the caliphate. They were all subject to the ruling of the central authority and the adopted state religion was Islam, Under the Islamic religion, it is an obligatory religious duty to pay tax by all members of the society. This tax is the fourth in the hierarchy of five pillars of Islam" (Agbetunde, 2004).

Besides this religiously established tax, Agbetunde, 2004, gave other forms of taxes in the area to include:

"Zakat" or Jizta": These are religious taxes levied on all members of the community. Zakat is paid by all Muslims on the income and produces annually.

"Jangali": This was a form of tax levied on livestock. It is paid based on the number of animals the individual has. It is paid in cash though the amount could be converted to number of animals commensurate to the amount payable.

Kudi 'n kasa: This was a form of tax paid on the use of land for farming. It is paid either in cash or with crops. Shuka Shuka: This was a tax levied on crops planted on the land. It is paid with part of the crop planted. A review of the evolution of taxation during the colonial and post-colonial period by this author; Dada, 2007, shall be looked into.

\section{Taxation During Colonial Period In Nigeria}

The evolution of taxation during the colonial era can be reviewed from 1893 to 1960 when independence was attained. It must be appreciated from the onset that the British Governments resolve not to administer any colonized territory with funds raised from Britain necessitated the need to generate fund within the colonies. After the colonization of Lagos in 1893, Custom Duties became the first means of funds for the protectorate's General Administration as most goods came to Lagos by sea. This agrees with what obtained in the Niger-Delta pre-colonial times where the kings made Europeans to pay taxes before trading.

The Northern protectorate was already used to tax and it is said to have an effective tax system in place already. The British officials found it easier to apply community tax in the North. Villages were jointly assessed to tax and village headmen had the responsibility of collecting tax from every adult member of the village and remit such collections to the colonial masters- The village headmen equally engaged agents to do direct collection. The practice culminated into the land Revenue proclamation of 1904 and Revenue proclamation of 1906. This was the beginning of direct tax in the Northern part of the Niger Area now called Nigeria, as enacted in the Native Revenue Ordinances of 1917. Beyond 1914, after the amalgamation, taxation as practiced in the Northern region was introduced to the Southern region in 1981 with a revised Native Revenue Ordinance of 1917, This led to double taxation in the South-West as towns and villages still paid tributes to Obas.

These events in the Yoruba and Benin Kingdoms did not hinder the colonial administration from introducing direct tax (community tax) in Eastern Nigeria. In 1929, the introduction of direct tax led to a demonstration that was initially conceived to be peaceful but later ended into a bloody clash. This left several women dead.

Other evolutionary steps before independence were the enactment of the companies Income Tax Ordinance No. 14 of 1934 and the provision of the Native Revenue Ordinance No 49 of 1940.

\section{Taxation During The Post-Colonial Period In Nigeria}

After independence there was the Binn's commission of 1964 and the Binn's Interim Revenue Allocation Committee of 1968. There was also the Aboyade Technical Committee on Revenue Allocation of 1978. Since the attainment of full federal Status and independence, there has been various evolutional tax enactment and proclamations with a number of amendments. This has recently left the country with the 
following statutory tax laws. The personal Income Tax Act No. 104 of 1993 which gives the legal basis for charging profits from Trade, Business, Professions or vocation and from any sources inside or outside Nigeria.

Corporate bodies are charged under Companies Income Tax Act (CITA) Cap 60, laws of the Federal Republic of Nigeria makes provision for the granting of tax relief to pioneer companies. All companies engaged in Petroleum Exploration hi Nigeria are charged to tax under the Petroleum Profit Tax Act of 1990. All purchases of chargeable goods and services are expected to pay 5\% of the purchase price as tax under the provision of value Added Tax of 1993. Others are: The customs and Excise Management Act Cap 84 1990. The Development levy payable to states, the land use Act of 1978 and a host of other state taxes

\section{Tax Administration In Nigeria}

Fasoto (2008) in his paper presentation on the topic "general overview of tax administration" at the 2008 Stakeholders' conference for Professional Associations (17th April, 2008), explained tax administration and the institutional arrangements involved in tax administration in Nigeria. These shall be considered now.

However, tax administration refers to the management and control of the whole gamut of the system by the government. (Fasoto, 2008), According to him, Lax administration is a foundation for effective revenue generation by any government. In his words "the strength of a fax system, lies in its effective administration". In Nigeria, the responsibility for the administration of the taxes is entrusted to the Federal Inland Revenue Service and the State Internal Revenue Service, The service appoints inspectors who carry out the work of assessment for Income Tax, Education Tax, Capital Gains Tax, Value Added Tax (VAT), and Banks who collect these taxes on their behalf (Fasoto, 2008).

\section{Federal Tax Institutions}

\section{Institutional Arrangements}

According to Fasoto (2008), at the Federal level, there are two major institutions in charge of taxation. They are the Federal Inland Revenue Service (FIRS) established by Act No. 13 of 2007 and the Nigerian Custom Service (NCS) established by Act No. 13 of 2007. In his words "apart from these two, there is also the Joint Tax Board established by the Personal Income Tax Act, 1993, which is not involved in tax administration as such but exists to harmonize taxation at Federal, State and Local Government levels as well as to advise the Federal Government on nation-wide aspects of Nigeria taxation, if called upon to do so." Federal Inland revenue Service (FIRS) which is an operational arm of Federal Board of Inland Revenue (FBIR) administer companies income tax, petroleum profit tax and personal income tax for some personnels in military related service among others (Agbetunde, 2004).

\section{STATE TAX INSTITUTIONS}

According to Fasoto (2008), at the State level, the State Board of Internal Revenue (SBIR) established by Section 85A (1) of Personal Income Tax Act (PITA) No. 104 of 1993. It administers Personal Income Tax, (PIT) generally and capital gains tax for individuals (Agbetunde, 2004).

\section{Local Government Tax Institutions}

According to Fasoto (2008), section 85D and 85E of PITA provide for a local government Revenue Committee (LGRC) as $\mathrm{n}$ institution in charge of tax administration at the local Government level. It is responsible for assessment and Election of, as well as accounting for all taxes, lines and rates Fasoto, 2008).

\section{Problems With Tax Administration In Nigeria As Well As Lagos State}

"The inadequacy of existing framework on tax administration a major challenge for tax administration in Nigeria. The current system of tax administration is also being described by some experts as being ineffective because of the poor co-ordination of government agencies involved in tax collection and administration" (Financial Standard, August 7, 2008, Pg 13).

The ineffectiveness in tax administration is seen as responsible for the alleged cases of corruption that have gone unpunished in the remittance of revenue to the Federation account by relevant tax collecting agencies in the country financial standard, Aug. 7, 2008, Pg 13).

According to Ifueko Omoigui - Okauru, Chairman Federal Inland Revenue Service (FIRS), the Nigerian tax system is a difficult and clumsy arrangement, often seen by foreign observers as complex, inept and corrupt. This situation, she believes, encourages high-level of tax avoidance and evasion by both individuals and corporate organisations. This position was corroborated by Barr. Babatunde Raji Fashola (SAN) Executive Governor of Lagos State an usurpation of power 2007. Hence the re-organization of tax administration in Lagos State under his government. Also, there has not been increased application of Information Technology tools in tax administration at all levels of government to facilitate continuous exchange of information between one tax 
authority and the other, as well as between the tax authorities and other relevant government agencies (Business Day, August 20, 2007, Pg. 27).

There is also the dearth of adequately trained, well equipped and motivated tax administrators and personels. Furthermore, there is the inability of public office holders to persuade more people to pay their taxes. This is largely a truism due to mounting concern over the level of corruption perpetrated by public office holders (Financial Standard August 7, 2008, Pg 13).

\section{Fiscal Policy Analysis}

Todaro and Smith (2006) asserted that there were two traditional purpose of taxation in 3rd World Countries. Firstly, tax concessions and similar fiscal incentives have been thought of as a means of stimulating private enterprises. Such concessions and incentives have typically been offered to foreign private investors to induce them to locate their enterprises in the developing country. The second purpose of taxation which they identified as the mobilization of resources to finance public expenditure is by far the more important.

In all less developed countries, irrespective of their ideological orientation, economic and social progress largely depends on the government ability to generate sufficient revenue to finance an expanding program of essential, non-revenue yielding public services such as health, education, trans port, communication and other components of the economic and social infrastructure. In their view, taxation potential of a country depends on the following five factors:

"In many developing countries (Nigeria inclusive) the gap between what is supposed to be a progressive tax structure and what different income groups actually pay can be substantial. Progressive tax structure on paper often turn out to be regressive taxes in practice, in that the lower and middle income groups pay a proportionately larger share of their incomes in taxes than the upper-income groups. The reasons for this are simple. The poor are often taxed at the source of their incomes or expenditures (by withholding taxes from wages, general poll taxes or indirect taxes levied on the retail purchase of goods). By contrast, the rich derive by far the largest part of their incomes from the return on physical and financial assets, which often go unreported. They often also have the power and ability to avoid paying taxes without fear of Todaro and Smith, (2006), therefore, suggested that policies to enforce progressive rates of direct taxation on income and wealth especially at the highest levels are what are most needed in this area of redistribution activity.

\section{Methodology}

The data that would be generated for the purpose of this research study is be basically primary data that would be used in generating questionnaire which will be administered to the civil servant employee of Lagos state and this was carried out at the Alausa office with the help of Assistant Director Finance and investment $\mathrm{Mr}$ Peter Medunoye and Pension Officer Mr Afees Oyebo (both employee of Lagos State Pension Commission, Necca house, Ikeja, Lagos), they are equally co-author of this research study.

However, the study population comprises 150 civil servant employee of Lagos state and it is made up of male and female altogether. More so, the population also has different material status from single to married employees.

However, Spearman's rank correlation coefficient will be adopted in this study. Spearman's rank correlation coefficient or Spearman's rho, named after Charles Spearman and often denoted by the Greek letter $\rho$ (rho) or as, is a non-parametric measure of statistical dependence between two variables. It assesses how well the relationship between two variables can be described using a monotonic function. If there are no repeated data values, a perfect Spearman correlation of +1 or -1 occurs when each of the variables is a perfect monotone function of the other. Therefore Spearman's coefficient can be used when both dependent (outcome; response) variable and independent (predictor) variable are ordinal numeric, or when one variable is a ordinal numeric and the other is a continuous variable. However, it can also be appropriate to use Spearman's correlation when both variables are continuous and the formular is as follows;

$\mathrm{R}=1-6 \sum \mathrm{d} 2$

$\mathrm{n}(\mathrm{n} 2-1)$

Where $\mathrm{d}=$ the difference between the ranks of each pair. $\mathrm{n}=$ number of paired observations

\begin{tabular}{|l|l|}
\hline Correlation Range & Strength of Association \\
\hline \pm 0.70 to $\pm \mathbf{1 . 0 0}$ & Strong \\
\hline \pm 0.40 to $\pm \mathbf{0 . 6 9}$ & Moderate \\
\hline \pm 0.25 to $\pm \mathbf{0 . 3 9}$ & Weak \\
\hline \pm 0.10 to $\pm \mathbf{0 . 2 4}$ & Very Weak \\
\hline \pm 0.00 to $\pm \mathbf{0 . 0 9}$ & None \\
\hline
\end{tabular}

Source: Nyang, (2005). 


\section{HYPOTHESIS ONE}

\section{Research Hypotheses}

Null Hypothesis (Ho): Taxation as a fiscal policy instrument cannot be used for income redistribution among the Lagos Civil Servants.

Alternative Hypothesis (H1): Taxation as a fiscal policy instrument can be used for income redistribution among the Lagos civil servants.

\section{HYPOTHESIS TWO}

Null Hypothesis (Ho): Income re-distribution cannot improve the welfare of Lagos State Civil Servants. Alternative Hypothesis (H1): Income re-distribution can improve the welfare of Lagos State Civil Servants.

XVI. RESULT

Data Presentation and Analysis, Analysis Of Questionnaire Table 1 Sex Distribution

\begin{tabular}{|l|l|l|l|l|l|l|l|}
\hline Responses & $\begin{array}{l}\text { Frequenc } \\
\mathrm{y}\end{array}$ & $\begin{array}{l}\text { Cumulative } \\
\text { Frequency }\end{array}$ & $\begin{array}{l}\text { Response } \\
\mathrm{s}\end{array}$ & $\begin{array}{l}\text { Frequenc } \\
\mathrm{y}\end{array}$ & $\begin{array}{l}\text { Cumulative } \\
\text { Frequency }\end{array}$ & $\begin{array}{l}\text { Percentag } \\
\mathrm{e}\end{array}$ \\
\hline Male & 98 & 98.0 & 65.33 & Single & 78 & 78.0 & 52.00 \\
\hline Female & 52 & 150.0 & 34.67 & Married & 72 & 150.0 & 48.00 \\
\hline Total & 150 & & 100.0 & & 150 & & 100.0 \\
\hline
\end{tabular}

Source: Field Survey 2012

From the result the result above, 98 out of 150 respondents are male and this gives $65.33 \%$ of the whole respondents and 52 out of 150 respondents and this represent $34.67 \%$ of the total respondents. We can then conclude from the analysis above that there are more male respondents in the research study.

More so, it was also known from the result above that 78 out of 150 respondents are single and this constitutes $52 \%$ of the whole respondents while 72 out of 150 respondents are married and this gives $48 \%$ of the total respondents. Therefore we can conclude that there are more single respondents in the research than married respondents.

TABLE 2 AGE DISTRIBUTION

\begin{tabular}{|l|l|l|l|}
\hline RESPONSES & FREQUENCY & $\begin{array}{l}\text { Cumulative } \\
\text { Frequency }\end{array}$ & Percentage \\
\hline Below 25 years & 42 & 42.0 & 28.00 \\
\hline Between 25-35 years & 68 & 10.0 & 45.33 \\
\hline Between 36-45 years & 28 & 138.0 & 18.67 \\
\hline 46 and above & 12 & 150.0 & 8.00 \\
\hline Total & 150 & & 100.0 \\
\hline
\end{tabular}

Source: Field survey 2012

The table above revealed that 42 respondents are below 25 years and this represents $28 \%$ of the total respondents while 68 respondents are between age 25-35 years and this gives $45.33 \%$ of the total respondents. However, 28 respondents are between age $36-45$ years and this gives $18.67 \%$ of the whole respondents while 12 respondents are between the ages of 46 and above years and this constitutes $8 \%$ of the total respondents. From the above analysis we can then deduced that respondents between 25-35 years of age are more in the research study.

TABLE 3 Educational Qualification Distribution

\begin{tabular}{|l|l|c|c|}
\hline RESPONSES & FREQUENCY & Cumulative Frequency & Percentage \\
\hline WAEC & 12 & 12.00 & 8.00 \\
\hline NCE/OND & 25 & 37.00 & 16.67 \\
\hline HND/B.SC & 88 & 125.00 & 58.66 \\
\hline M.Sc./MBA & 25 & 150.00 & 16.67 \\
\hline Total & 150 & & 100.0 \\
\hline
\end{tabular}

Source: Field survey 2012 
The Table above shows that 12 out of 150 respondents have West African Examination Council (WAEC) qualification and this gives $8 \%$ of the wholke respondents while 25 out of 150 respondents have National College of Education/ Ordinary National Diploma (NCE/OND) qualification. However, 58.66\%\% of the total respondents has Higher National Diploma/ Bachelor of Science (HND/B.SC) qualification while $16.67 \%$ have Masters degree (M.Sc/MBA), therefore we can then conclude that respondents with Higher National Diploma/ Bachelor of Science (HND/B.SC) qualification are more in the research study.

TABLE 4

ANALYSIS OF RESPONDENTS BY NUMBER OF YEARS OF WORKING EXPERIENCE

\begin{tabular}{|c|c|c|c|}
\hline RESPONSES & Frequency & Cumulative & Frequency|Percentage \\
\hline Less Than 1 year & 10 & 10.00 & 6.67 \\
\hline $1-5$ years & 25 & 35.00 & 16.67 \\
\hline 6-10 years & 85 & 120.00 & 56.66 \\
\hline $\begin{array}{l}11 \text { years and above } \\
\text { Above }\end{array}$ & 30 & 150.0 . & 20.00 \\
\hline Total & 150 & & 100.0 \\
\hline
\end{tabular}

Source: Field survey 2012

Table 4 above shows that $6.67 \%$ of the total respondents have less than a year experience in as a civil servant while $16.67 \%$ of the whole respondents have between 1-5 years experience as a civil servant. However, $56.66 \%$ of the total respondents has 6-10 years experience as a civil servant while $20 \%$ of the whole respondents have 11 years and above, therefore we can then conclude that respondents with $6-10$ years experience has more experience than any other respondents in the research study.

TABLE 5

RESULT OF GENERAL QUESTIONS DISTRIBUTED TO THE RESPONDENTS

\begin{tabular}{|c|c|c|c|c|}
\hline Questions & Response & Frequency & $\begin{array}{l}\text { Cumulative } \\
\text { Frequecy }\end{array}$ & Percentage (\%) \\
\hline $\begin{array}{l}\text { 1.The Nigerian tax system } \\
\text { is efficient and effective }\end{array}$ & $\begin{array}{l}\text { COLUMN } \\
\text { SA } \\
\text { SD } \\
\text { A } \\
\text { D } \\
\text { U }\end{array}$ & $\begin{array}{l}10 \\
100 \\
10 \\
20 \\
10\end{array}$ & $\begin{array}{l}10.0 \\
110.0 \\
120.0 \\
140.0 \\
150.0\end{array}$ & $\begin{array}{r}6.67 \\
66.67 \\
6.67 \\
13.33 \\
6.66\end{array}$ \\
\hline $\begin{array}{l}\text { 2. Taxation to the } \\
\text { government and its fiscal } \\
\text { need is a pillar and } \\
\text { facilitator of development } \\
\text { in Lagos State. }\end{array}$ & $\begin{array}{l}\text { SA } \\
\text { SD } \\
\text { A } \\
\text { D } \\
\text { U }\end{array}$ & $\begin{array}{l}150 \\
- \\
- \\
- \\
-\end{array}$ & $\begin{array}{c}150.0 \\
- \\
- \\
-\end{array}$ & $\begin{array}{l}100.00 \\
- \\
- \\
-\end{array}$ \\
\hline $\begin{array}{l}\text { 3. Taxation is one of the } \\
\text { means by } \\
\text { government } \\
\begin{array}{l}\text { which } \\
\text { revenue. }\end{array}\end{array}$ & $\begin{array}{l}\text { SA } \\
\text { SD } \\
\text { A } \\
\text { D } \\
\text { U }\end{array}$ & $\begin{array}{c}150 \\
- \\
- \\
- \\
-\end{array}$ & 150.0 & 100.0 \\
\hline $\begin{array}{l}\text { 4. Taxation contributes to } \\
\text { the growth and } \\
\text { development of Nigerian } \\
\text { economy. }\end{array}$ & $\begin{array}{l}\text { SA } \\
\text { SD } \\
\text { A } \\
\text { D } \\
\text { U }\end{array}$ & $\begin{array}{r}130 \\
20 \\
- \\
- \\
-\end{array}$ & $\begin{array}{l}130.0 \\
150.0\end{array}$ & $\begin{array}{l}86.67 \\
13.33\end{array}$ \\
\hline $\begin{array}{l}\text { 5. Revenue generated } \\
\text { from tax in Lagos state is } \\
\text { sufficient for the public } \\
\text { expenditure. }\end{array}$ & $\begin{array}{l}\text { SA } \\
\text { SD } \\
\text { A } \\
\text { D } \\
\text { U }\end{array}$ & $\begin{array}{l}150 \\
- \\
- \\
- \\
-\end{array}$ & 150.0 & 100.0 \\
\hline $\begin{array}{l}\text { 6. Taxation aids } \\
\text { redistribution of wealth } \\
\text { and income among Lagos }\end{array}$ & $\begin{array}{l}\text { SA } \\
\text { SD } \\
\text { A }\end{array}$ & $\begin{array}{r}120 \\
10 \\
-\quad \\
\end{array}$ & $\begin{array}{l}120.0 \\
130.0\end{array}$ & $\begin{array}{r}80.00 \\
6.67\end{array}$ \\
\hline
\end{tabular}




\begin{tabular}{|c|c|c|c|c|}
\hline State Civil Servant. & $\begin{array}{l}\mathbf{D} \\
\mathbf{U}\end{array}$ & 20 & 150.0 & 13.33 \\
\hline $\begin{array}{l}\text { 7. The Tax imposed by } \\
\text { the Lagos State } \\
\text { Government on its civil } \\
\text { servant is very high, } \\
\text { making them worse off. }\end{array}$ & $\begin{array}{l}\text { SA } \\
\text { SD } \\
\text { A } \\
\text { D } \\
\text { U }\end{array}$ & $\begin{array}{l}150 \\
- \\
- \\
- \\
-\end{array}$ & 150.0 & 100.0 \\
\hline $\begin{array}{l}\text { 8. Taxation is a tool for } \\
\text { raising the quality of life } \\
\text { of all citizens }\end{array}$ & $\begin{array}{l}\text { SA } \\
\text { SD } \\
\text { A } \\
\text { D } \\
\text { U }\end{array}$ & $\begin{array}{c}100 \\
50 \\
- \\
- \\
- \\
- \\
\end{array}$ & $\begin{array}{l}100.0 \\
150.0\end{array}$ & $\begin{array}{l}66.67 \\
33.33\end{array}$ \\
\hline $\begin{array}{l}\text { 9. Tax evasion is very } \\
\text { high in Lagos State. }\end{array}$ & $\begin{array}{l}\text { SA } \\
\text { SD } \\
\text { A } \\
\text { D } \\
\text { U }\end{array}$ & $\begin{array}{l}150 \\
- \\
- \\
- \\
-\end{array}$ & 150.0 & 100.00 \\
\hline $\begin{array}{l}10 . \quad \text { Income } \\
\text { distribution can improve } \\
\text { welfare of Lagos State } \\
\text { Civil Servants. }\end{array}$ & $\begin{array}{l}\text { SA } \\
\text { SD } \\
\text { A } \\
\text { D } \\
\text { U }\end{array}$ & $\begin{array}{l}88 \\
22 \\
40 \\
- \\
-\end{array}$ & $\begin{array}{r}88.0 \\
110.0 \\
150.0\end{array}$ & $\begin{array}{l}58.67 \\
14.67 \\
26.66\end{array}$ \\
\hline Total & & 150 & & 100.0 \\
\hline
\end{tabular}

Source: Field survey 2012

Where SA- Strongly Agree, SD- Strongly Disagree, A- Agree, D- Disagree, U- Undecided. The table above shows in question (1) that 10 out of 150 respondents strongly agree with the question and this gives $6.67 \%$ of the total respondents, 100 out of 150 respondents strongly agree with the question and this gives $66.67 \%$ of the whole respondents, while 10 out of 150 respondents agreed with the question and this $6.67 \%$ of the total respondents. However, 20 out of 150 respondents disagree with the question and 10 respondents are undecided. Therefore we can conclude that Nigerian tax system is not efficient and effective.

Further more, all the respondents in (2) strongly agree that taxation to the government and its fiscal need is a pillar and facilitator of development in Lagos state while in (3) all the respondents strongly agree that taxation is one of the means by which government raises revenue. More over, in (4) 130 out of 150 respondents strongly agree with the question and this gives $86.67 \%$ of the whole respondents while 20 out of 150 respondents strongly disagree with the question and this gives $13.33 \%$ of the whole respondents and we can then conclude that taxation contributes to the growth and development of Nigerian Economy.

More so, all the respondents in (5) strongly agree that revenue generated from tax in Lagos state is sufficient for the Public Expenditure, while in (6) 120 respondents strongly agree with the question and this represent $80 \%$ of the total respondents while 10 out of 150 respondents strongly disagree with the question and this gives $6.67 \%$ of the whole respondents and 20 out of 150 respondents disagree with the notion and this gives $13.33 \%$ of the whole respondents. Therefore we can conclude that taxation aids redistribution of wealth and income among Lagos state civil servant.

More over, all the respondents in (7) strongly agree that the tax imposed by the Lagos state Government on its civil servant is very high, making them worse-off while in (8) 100 out of 150 respondents strongly agree with the notion and 50 out of 150 respondents strongly disagree with the notion, therefore we can conclude that taxation is a tool for raising the quality of life of all Lagos citizens.

More so, all the respondents in (9) strongly agree that tax evasion is very high in Lagos state while in (10) 88 out of 150 respondents strongly agree with the notion and this gives $58.67 \%$ of the total respondents while 22 out of 150 respondents strongly disagree with the notion and this represent $14.67 \%$ of the total respondents and 40 out of 150 respondents agree with the notion and this constitutes $26.66 \%$ of the total respondents, therefore we can then conclude that income re-distribution can improve welfare of Lagos State civil servants. 


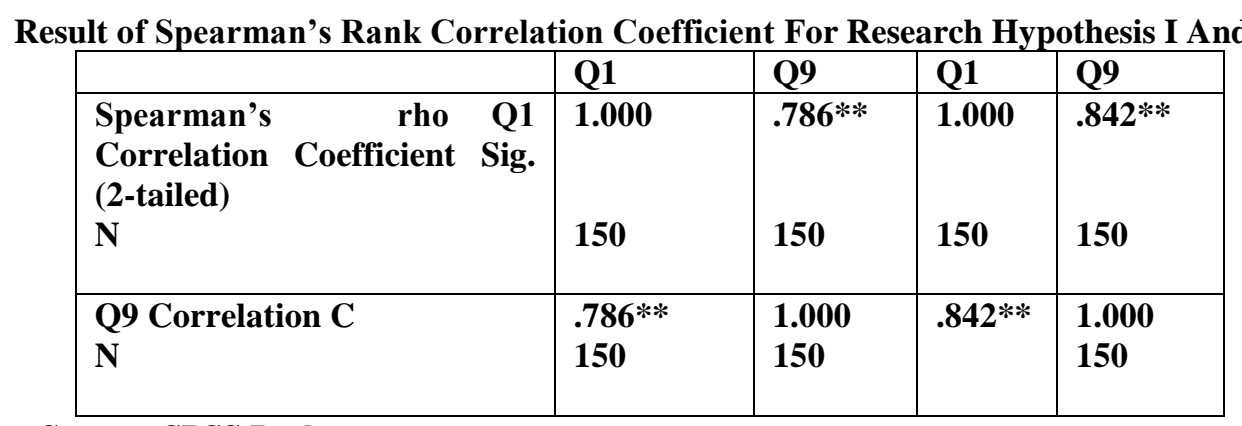

Source: SPSS Package

Decision Rule: If the Spearman's rank correlation H calculated is greater than Spearman's rank correlation $\mathrm{H}$ tabulated, we accept the alternative hypothesis and reject the null hypothesis. The tabulated value use here is $5 \%$ level of significance that is $* * \mathrm{P}<0.05$ and vice versa. However, it was revealed from the result above that the spearman's rank correlation coefficient results for research hypothesis one, and two values is given as 0.786 and 0.842 , which established that there is a positive and strong relationships.

More over, since the spearman's rank correlation coefficient calculated values (0.786 and 0.842) are all greater than Spearman's rank correlation coefficient tabulated value using $5 \%$ level of significance ** $\mathrm{P}<0.05$ we then accept alternative hypothesis in the two hypotheses and reject the null hypotheses in the two hypotheses, then conclude that Taxation as a fiscal policy instrument can be used for income redistribution among the Lagos civil servants and that income re-distribution has improved the welfare of Lagos State Civil Servants.

XVII.

XVIII.

\section{Recommendation and Conclusion} Recommendation

In view of this study, the following recommendations shall be made.

- Government should ensure that the revenue generated from tax paid is well utilized to provide essential services for the masses. For instance, good road, efficient transport network, constant supply of electricity and pipe-borne water as well as health facilities because "health is wealth".

- The tax administrators should be well remunerated and their condition of services improved for more efficient performance and to ensure honesty among them.

- Efforts should be intensified to recruit and retain adequately trained, qualified and experienced revenue staff.

- There should be effective communication of government policies and strategies on subjects relating to taxation.

- Government should create a transparent and accountable system to ensure that tax is used to build a more equitable society, redistribute wealth and attract investment flows into the state.

\section{Conclusion}

The research study takes a look at taxation as a fiscal policy instrument for income re-distribution among Lagos State civil servants. However, the following are some of the findings from the research study:

- The current system of tax administration is not efficient. This is caused by poor co-ordination of government agencies involved in tax collection and administration. This violates canon of efficiency.

- The general opinion of the populace is that taxation is a means by which government raises revenue.

- Taxation to the government and its fiscal need is a pillar and facilitator of development.

- Taxation contributes to the growth and development of Nigeria economy.

- Revenue generated from tax is not sufficient for the public expenditure.

- Taxation is a tool for raising the quality of life of all citizens.

- Lack of statistics, inadequate infrastructure, weak tax enforcement, outdated laws and irresponsibility of the government are responsible for tax evasion by Nigerians.

- Tax is imposed by the government to raise revenue, redistribute income, control inflation and to protect infant industries.

- Taxation aids redistribution of wealth and income.

- Taxes collected by government give taxpayers the right to enjoy public amenities. 
The tax system should be squarely focused on the main objective of stimulating economic growth and enabling economic development as well as serve as reflection of the deep rooted need for improving per capita income of all the people living in Lagos and Nigerians as a whole.

In conclusion, the price system promotes income inequalities thereby creating poverty and agony amidst of plenty in the economy. Government therefore, intervened to correct unjust inequalities of income through introduction of tax system, among other programmes, desired to take more from the rich and less from the poor and to achieve economic growth and development. However, the Government should bridge the gap between the rich and the poor by taxing the rich high and using the tax proceeds to provide basic amenities for the masses. Based on the findings, taxation can indeed be used to correct income inequalities and to achieve economic growth and development in Lagos state and Nigeria as a whole and it is a tool for raising the quality of life of all citizens.

\section{References}

[1] Adebayo, A. (1999) Simplified Economics ( $2^{\text {nd }}$ Ed). Lagos: African International Publishing Ltd.

[2] Ademowo, O. A. (1999) Taxation on Welfarism of Nigerian Workers, a Journal of Social Science, University of Ibadan, Vol, 4, pages $1-16$, University Press, Ibadan.

[3] Agbetunde, L. A. (2004). Principles and Practice of Nigerian Personal Income Tax. Lagos: Feetal consulting.

[4] Ajakaiye, O. O. (2002) Impact of Value added tax on key sectoral and macroeconomics aggregates, a Journal of Social Science, University of Ibadan, vol. 4, pages 23 - 51, University Press, Ibadan.

[5] Anyanwuocha, R. A. (1993). Fundamentals of Economics for Senior Secondary Schools (8 ${ }^{\text {th }}$ Ed). Onitsha: Africana Feb Publishers.

[6] Chete and Adeoye (2003) Taxation as a fiscal policy tool for development of Nigerian economy, a Journal of Social Science, University of Ibadan, vol. 4 pages 63 - 72, University Press, Ibadan.

[7] Dada, B. (2007). Public Finance in Nigeria, Lagos: F. B. Ventures.

[8] Fagbemi, O. A. (1964). Taxation as a means of economic development Lagos: Fadec Ltd.

[9] Fasoto, F. (2008, April), General Overview of Tax Administration. Paper Presented at 2008 Stakeholders' Conference for Professional associations, Lagos.

[10] Iheanyi, N. (2007, August, 13) Huge tax Revenues: Does it correlate with infrastructural development? Business Day, Pg 29.

[11] Iheanyi, N. (2007, August, 20) Why we must keep pace with Information Technology, Business Day. Pg 27,

[12] Iheanyi, N. (2007, August, 27) Businesses wait for National Tax Policy. Business Day. Pg 32.

[13] Iheanyi, N. (2007, July, 13) Non Utilization of Tax Proceeds: National Tax Policy will enable you hold State, Local Government responsible Business Day. Pg. 8.

[14] Ilemobayo, A. S. (1997). Public Finance in Nigeria. Lagos: Bunak Printing and Publishing Company.

[15] Lawal, A. (2005). Principle and Practice of Public Finance. Lagos: Ola Ventures.

[16] Nkechi, O. (2008, August, 27), Development an acceptable tax system in Nigeria. Financial Standard. Pg 13.

[17] Oji, N. (2000, May). Stimulating Economic Growth through an efficient tax system. Paper presented at the second Annual Tax Conference of the Chartered Institute of Taxation of Nigeria, Lagos.

[18] Olakunri, O. O. (2000, May) The Wealth of the Nation. Paper presented at the second Annual Tax Conference of the Chartered Institute of Taxation of Nigeria, Lagos.

[19] Todaro, M. P, Smith, S. C. (2006). Economic Development ( $8^{\text {th }}$ Ed), Kindersley (India); Dorling Pvt. Ltd. 